\title{
Development and in vitro Evaluation of Voriconazole Nanoparticle Formulation for Mucosal Application
}

\author{
Mukozal Uygulama için Vorikonazol Nanopartikül Formülasyonunun \\ Geliştirilmesi ve in vitro Değerlendirilmesi
}

\author{
(D) Seda RENÇBER*, (D) Sinem Yaprak KARAVANA \\ Ege University, Faculty of Pharmacy, Department of Pharmaceutical Technology, İzmir, Turkey
}

\begin{abstract}
Objectives: This study aimed to prepare and evaluate mucoadhesive nanoparticle formulations of voriconazole, an antifungal drug, for mucosal application. It was also aimed to develop and validate a HPLC method of voriconazole.

Materials and Methods: In this study, mucoadhesive nanoparticles containing voriconazole were prepared using a coating polymer of chitosan. The obtained nanoparticles were characterized via particle size, polydispersity index, zeta potential measurement, and mucoadhesion studies. Drug loading capacity was tested for determination of the voriconazole amount in the nanoparticles. In vitro drug release was also examined. The HPLC method was validated for linearity, accuracy, precision (repeatability and reproducibility), specificity, stability, limits of detection (LOD), and limit of quantification (LOQ). Results: In vitro characterization results of the mucoadhesive nanoparticle formulation containing voriconazole was found to be appropriate with a small particle size of $217.1 \pm 4.2 \mathrm{~nm}$, a narrow polydispersity index of $0.335 \pm 0.042,99.052 \pm 0.424 \%$ drug loading, and a positive zeta potential value of $+26.82 \pm 0.4$ $\mathrm{mV}$. According to a mucoadhesive study, it can be concluded that the nanoparticle was able to interact with mucin due to ionic interaction. Also, the turbidity of nanoparticle/mucin dispersion was higher than the turbidity of mucin dispersion itself. Based on the in vitro drug release, no burst effect was observed, indicating that voriconazole was homogeneously dispersed in the nanoparticle dispersion and that no significant amount of drug was adsorbed onto the nanoparticle surface. The release was found to follow a non-Fickian diffusion mechanism with first-order drug release. The proposed HPLC method was simple, highly sensitive with good linearity, accurate, precise, specific, and stable, showing that the method is useful for routine quality control. Conclusion: This study has shown that the mucoadhesive nanoparticle formulation containing voriconazole reported here is a promising candidate for the local treatment of mucosal diseases. The developed HPLC method can be succesfully applied to pharmaceutical preparations containing voriconazole. Key words: Voriconazole, mucoadhesive nanoparticle, chitosan, local application, HPLC
\end{abstract}

ÖZ

Amaç: Bu çalışma, mukozal uygulama için antifungal bir ilaç olan vorikonazolün mukoadezif nanopartikül formülasyonunu hazırlamayı ve değerlendirmeyi amaçlamıştır. Ayrıca vorikonazolün HPLC yöntemi geliştirilmiş ve valide edilmiştir.

Gereç ve Yöntemler: Bu çalışmada, kitozan kaplama polimeri kullanılarak vorikonazol içeren mukoadezif nanopartikül hazırlandı. Elde edilen nanopartikül formülasyonu, partikül boyutu, polidispersite indeksi, zeta potansiyeli ölçümü ve mukoadezyon çalışmaları ile karakterize edildi. İlaç yükleme kapasitesi nanopartikülde vorikonazol miktarının belirlenmesi için gerçekleștirildi. In vitro ilaç salınımı da incelendi. HPLC yöntemi doğrusalık, doğruluk, kesinlik (tekrar edilebilirlik ve tekrar elde edilebilirlik), özgünlük, stabilite, LOD ve LOQ ile valide edildi.

Bulgular: Vorikonazol içeren mukoadezif nanopartikül formülasyonu, 217.1 $\pm 4.2 \mathrm{~nm}$ küçük partikül boyutu, $0.335 \pm 0.042$ dar polidispersite indeksi, $\% 99.052 \pm 0.424$ ilaç yükleme kapasitesi, $+26.82 \pm 0.4 \mathrm{mV}$ pozitif zeta potansiyel değeri ile uygun bulunmuştur. Mukoadezyon çalıșmasına göre, nanopartikülün, iyonik etkileşim nedeniyle müsinle etkileşime girdiği sonucuna varılabilir. Ayrıca nanopartikül/müsin dispersiyonunun bulanıklığı, müsin dispersiyonunun bulanıklığından daha fazla bulunmuştur. In vitro ilaç salım çalışmasına göre, vorikonazolün nanopartikül dispersiyonunda homojen olarak dağılmış olduğu ve nanopartikül yüzeyi üzerinde önemli miktarda ilacın adsorbe edildiğini gösteren ani salım etkisi gözlemlenmemiştir. İlaç salımı, birinci dereceden ilaç salımı ile Fick Kanunu'na uymadığını göstermiştir. Önerilen HPLC yöntemi, rutin kalite kontrolü için basit, çok hassas, doğrusal, kesin, hassas, özgün ve stabildir.

Sonuç: Bu çalışma, vorikonazol içeren mukoadezif nanopartikül formülasyonunun, mukozal hastalıkların lokal tedavisinde umut verici bir aday olduğunu göstermiştir. Geliştirilen HPLC yöntemi, vorikonazol içeren farmasötik preparatlar için başarılı bir şekilde uygulanabilir.

Anahtar kelimeler: Vorikonazol, mukoadezif nanopartikül, kitosan, lokal uygulama, HPLC

*Correspondence: E-mail: sedarencber@gmail.com, Phone: +90 5055267687 ORCID-ID: orcid.org/0000-0003-0172-2120

Received: 12.04.2017, Accepted: 13.07.2017

๑Turk J Pharm Sci, Published by Galenos Publishing House. 


\section{INTRODUCTION}

Voriconazole (VRZ) ((2R,3S)-2-(2,4-difluorophenyl)-3-(5fluoro-4-pyrimidinyl)-1-(1H-1,2,4-triazol-1-yl)-2-butan-2-ol) is a novel broad spectrum triazole antifungal agent for the treatment of serious infections caused by Aspergillus, Fusarium, Scedosporium, and resistant Candida species.' Since its release by the United States Food and Drug Administration in May 2002, VRZ has established itself as the first-line treatment for invasive aspergillosis and proven useful in other fungal infections that are resistant and refractory to standard antifungal therapies., ${ }^{2,3}$ In Europe, the drug has been approved by the European Medicines Agency (EMEA) since March 2002 for the treatment of invasive aspergillosis, fluconazole-resistant strains of Candida species, and serious infections caused by Scedosporium spp. and Fusarium spp. (EMEA 2002). VRZ is a synthetic derivative of fluconazole, one of the triazole moieties in fluconazole is replaced by a fluoropyrimidine group and an alpha methyl group is also introduced. It is more active than fluconazole and itraconazole against Candida species. 4,5 The drug has reported adverse effects of visual disturbances, hepatic toxicity, headache pain, and dermatologic reactions, as well as serious cytochrome P450-mediated drug interactions. ${ }^{6,7}$ Because of the wellreported adverse effects, drug interaction, and the ominous risk of drug resistance of systemic VRZ, a local formulation without the aforementioned risks is needed in clinical practice.

Local drug delivery is frequently used for the treatment of localized disorders. The main advantages of local administration are the ability to deliver the active agent directly to the site and the maintenance of the required concentration of active substance at the site for a prolonged period. ${ }^{8} \mathrm{~A}$ great deal of attention has been devoted to the development of mucoadhesive drug delivery systems. Mucoadhesive nanoparticle (NP) formulations have raised widespread interest for their recognised potential for improving the bioavailability of drugs and maintaining the local effect in the targeted area. The increased contact time and localization of the drug is due to applying nanoparticles (NPs) of VRZ, which are made mucoadhesive, thus enhancing its delivery. This approach prolongs the activity of the active substance as well as reduces the frequency of administration. A possible added advantage of mucoadhesive NP is that particulates have the advantage of being relatively small and are thus accepted by patients.

NPs coated with chitosan (CSH) have attracted a special interest for drug delivery through the mucosal routes because of their ability to interact with the negatively charged sites on the mucosa surface, prolonged retention time, mucoadhesive properties, and increased local concentration of NPs.9.10 $\mathrm{CSH}$, which is strong mucoadhesive, nontoxic, cationic, biocompatible, biodegradable, and has mucoadhesiveness as well as antibacterial, antifungal, and antitumor activity, is a suitable polymer for mucoadhesive drug formulations.11-13 These functional properties provide suitability and extensive pharmaceutical applications; therefore, CSH-coated NPs have reached an important position in the arena of drug delivery.

The objective of this study was to prepare a mucoadhesive
NP formulation of VRZ. CSH was used as coated polymer to provide the mucoadhesive property to the NP system. In vitro characterization of the prepared mucoadhesive NP formulation was performed. An additional aim was to develop and validate a simple, rapid, and economic high-performance liquid chromatography (HPLC) method for the analysis of VRZ as per International Council for Harmonisation of Technical Requirements $(\mathrm{ICH})$ guidelines.

\section{MATERIALS AND METHODS}

\section{Materials}

VRZ were obtained from Sigma-Aldrich (St Louis, MO, USA). Eudragit (EUD) RS 100 as gifts from Karadeniz Chemical Company (Karadeniz, Turkey). High-molecular-weight CSH (Brookfield viscosity $[1 \%, \mathrm{~m} / \mathrm{V}$, in $1 \%$ acetic acid solution at $25^{\circ} \mathrm{C}$; $800,000 \mathrm{mPa} . \mathrm{s} .75 \%$ deacetylated) and HPLC grade acetonitrile were purchased from Sigma-Aldrich. All other materials were of analytical grade.

\section{HPLC system}

HPLC was conducted using a Hewlett Packard series 11001200 HPLC apparatus (Santa Clara, CA, USA) equipped with an UV detector set at $255 \mathrm{~nm}$ using a C18 column $(5 \mu \mathrm{m}, 4.6 \times 250$ $\mathrm{mm}$ ). The injection volume was $50 \mu \mathrm{L}$. The mobile phase, fluxed at $1.5 \mathrm{~mL} / \mathrm{min}$, was a mixture of acetonitril:water $(35: 65 \mathrm{v} / \mathrm{v})$. The flow rate was maintained at $25 \pm 1^{\circ} \mathrm{C}$.

\section{Preparation of stock solutions and standard working solution}

Stock solution of VRZ was prepared by dissolving $1 \mathrm{mg}$ of drug in $10 \mathrm{~mL}$ methanol. VRZ concentrations in the working solution chosen for the calibration curves were 2.5, 5, 10, 15, 20 and 30 $\mu \mathrm{g} / \mathrm{mL}$. All samples were filtered through an aqueous $0.2-\mu \mathrm{m}$ pore-size membrane filter before injection.

\section{Validation of HPLC method}

The developed HPLC method was validated according to ICH guidelines including the determination of linearity, calibration curve, accuracy, precision (repeatability and reproducibility), specificity, stability, limit of detection (LOD), and limit of quantification (LOQ) of analysis in spiked samples. ${ }^{14-16}$

\section{Specificity}

The specificity of an analytical method is its ability to measure accurately and specifically the analyte in the presence of components that may be expected to be present in the sample matrix. To evaluate the specificity of the analytical method, the VRZ test solution, methanol, and mobile phase were injected into the chromatographic system. These parameters were determined by comparing the chromatograms of the VRZ standard, methanol, and mobile phase.

\section{Linearity}

The linearity between the peak area and concentration was analyzed using a calibration curve obtained from standard solutions of VRZ ( 2.5 to $30 \mu \mathrm{g} / \mathrm{mL}$ ). In addition, it was evaluated using linear regression analysis, which was calculated by the least-square regression analysis. 


\section{Accuracy and recovery}

The accuracy study is the closeness of test results obtained by the method to the true value and is defined recovery. The prepared three standard solutions $(10,15,20 \mu \mathrm{g} / \mathrm{mL}$ ) were injected six times at different levels as a test sample.

\section{Precision}

The precision of the assay was determined with repeatability and reproducibility. Repeatibilty was calculated from six replicated injections of freshly prepared VRZ test solution in the same equipment at a concentration value of $10 \mu \mathrm{g} / \mathrm{mL}$ of the intended test concentration value on the same day. For reproducibility study, $10 \mu \mathrm{g} / \mathrm{mL}$ sample was prepared and injected into HPLC system as per the test procedure. The peak area of VRZ was determined and precision was reported as \% RSD.

\section{$\angle O D$ and $L O Q$}

$L O D$ and $L O Q$ tests for the procedure are performed on samples containing very low concentrations of analyte. LOD is defined as the lowest amount of analyte that can be detected above baseline noise; typically, three times the noise level. $L O Q$ is defined as the lowest amount of analyte that can be reproducibly quantitated above the baseline noise that gives $\mathrm{S} / \mathrm{N}=10$.

\section{Stability}

For a short-term stability study, a sample solution of VRZ was prepared and analyzed initially and also at the end of 48 hours by keeping the solution at room temperature.

\section{Preparation of mucoadhesive NP formulation}

The NPs were prepared by adapting the spontaneous emulsification technique previously described by Bodmeier et al. ${ }^{17}$ The final preparation method was established in accordance with Rençber et al.'s ${ }^{18}$ study. In brief, $2.5 \%$ of EUD RS polymer and $0.05 \%$ VRZ were dissolved in $25 \mathrm{~mL}$ ethanol. The alcoholic solution mixture was added dropwise $(3 \mathrm{~mL} / \mathrm{min})$ to $50 \mathrm{~mL}$ of $0.025 \% \mathrm{w} / \mathrm{v}$ aqueous chitosan solution under continuous magnetic stirring at $800 \mathrm{rpm}$. The formed $\mathrm{CSH}$-coated NP was further stirred for 48 hours at room temperature.

Measurement of particle size (PS), polydispersity index (PI) and zeta potential (ZP)

The PS, PI and ZP were measured at $25^{\circ} \mathrm{C}$ using a Nano-ZS Zetasizer (Malvern Instruments, Malvern, UK). The PS and PI values were obtained by averaging ten measurements at an angle of $173^{\circ}$ using disposable cells. The ZP was calculated from the electrophoretic mobility using the Helmholtz-Smoluchowski equation under an electrical field of $40 \mathrm{~V} / \mathrm{cm}$. The processing was performed using the software included within the system $(n=5)$.

\section{Mucoadhesive evaluation: ZP determination and turbidimetric measurement}

Two in vitro methods were used to assess the mucoadhesive evaluation of NP.19-21 In the first method, the mucoadhesive property of NP with VRZ was evaluated by measuring the changes of ZP on interaction with negatively charged mucin. The mucoadhesive NP containing VRZ was incubated at $37^{\circ} \mathrm{C}$ in
$0.1 \%$ mucin dispersion. The ZP of the NP was measured over 6 hours. The alteration of ZP of the CSH-coated NP with VRZ indicates interaction with mucin.

Turbidimetric measurements of mucoadhesive NP containing VRZ was compared with mucin dispersion at $650 \mathrm{~nm}$ by ultraviolet-visible spectrophotometer. The accurately mucoadhesive $\mathrm{NP}(5 \mathrm{~mL})$ was added to $5 \mathrm{~mL}$ aqueous mucin dispersion and stirred at $200 \mathrm{rpm}$. The turbidity of the dispersions was measured at certain time intervals over 6 hours and compared with the turbidity of the mucin dispersion. The increase in turbidity of mucin: mucoadhesive NP dispersion with VRZ indicated mucoadhesive property.

\section{Drug loading ( $D L$ ) capacity}

The DL capacity of NP was determined by dissolving $0.04 \mathrm{~mL}$ of the NP in $8 \mathrm{~mL}$ methanol with vortex, followed by a validated HPLC assay for VRZ. The DL capacity was calculated according to the following equations: ${ }^{18}$

$$
\mathrm{DL}=\frac{\text { Total amount of VRZ-The amount of free VRZ }}{\text { Total amount of formulation components) }} \times 100
$$

In vitro drug release studies

The release of VRZ from $4 \mathrm{~mL}$ of NP was assessed using a dialysis bag (cellulose membrane, 12,000-14,000-molecularweight cutoff Spectrum Labs, Rancho Dominguez, CA, USA into phosphate buffer saline (PBS) at $37^{\circ} \mathrm{C} \pm 0.5^{\circ} \mathrm{C}$, and stirred continuously with a magnetic stirrer at $300 \mathrm{rpm}$ for 24 hours. The amount of the drug in the receiving solution was analyzed using the validated HPLC method. Sink conditions were maintained in the receptor compartment during in vitro release studies $(n=5)$.

\section{Determination of drug release mechanism}

The dissolution data were fit to the Peppas equation, and best-fit parameters were calculated to determine the release mechanism of the tablets. ${ }^{22}$

\section{RESULTS}

HPLC system

An HPLC method for quantitative analysis of VRZ in mucoadhesive NP formulation was developed and validated. To evaluate the specificity of the analytical method, the VRZ test solution, methanol, and mobile phase were injected into the chromatographic system. There was no interference from the methanol and mobile phase at VRZ peaks. The chromatogram of the VRZ standard presented a peak in the retention time of $13.669 \mathrm{~min}$; the total analysis time was $15 \mathrm{~min}$ (Figure 1).

A6-point calibration curve was constructed covering a concentration range from 2.5 to $30 \mu \mathrm{g} / \mathrm{mL}$ for standard solution of bulk VRZ. The determination correlation coefficient $\left(R^{2}\right)$ for a regression line is 0.9931 with the linear regression equation $y=42.537 x-46.906$. The analyses of calibration are shown in Figure 2.

The HPLC area responses for accuracy determination were evaluated and the mean recovery data of VRZ were within the range of 89.702 and $105.500 \%$ (Table 1). The mean \% relative 


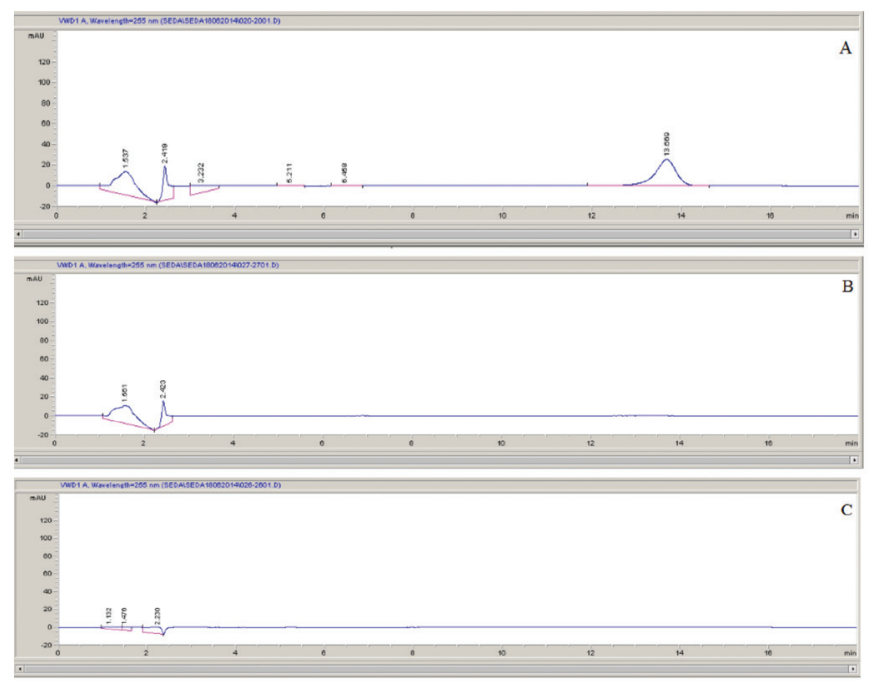

Figure 1. The chromatograms obtained of VRZ in standard solution (A), methanol (B) and mobile phase (C)

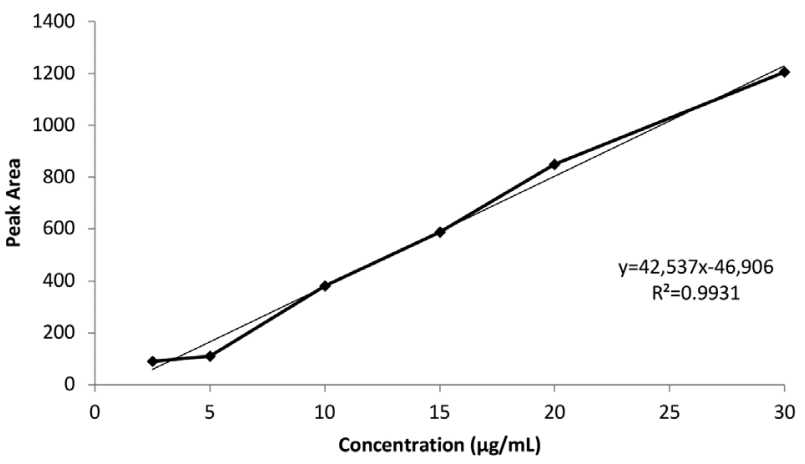

Figure 2. The regression line for VRZ

standard deviations (R.S.D.) were between 0.112 and $0.542 \%$, thereby satisfying the acceptance criteria for the study (R.S.D. maximum 2.0\%). Hence, the accuracy of the method was confirmed, this method can be used for further studies.

As Table 2 shows, the percentage of mean recovery values of precision study were found as $100.541 \%-100.616 \%$, with R.S.D. ranges 0.028-0.392.

The determined values of $L O D$ and $L O Q$ were $0.804 \mu \mathrm{g} / \mathrm{mL}$ and $1.608 \mu \mathrm{g} / \mathrm{mL}$, respectively.

During the storage of the solution at room temperature, the solutions were stable for 48 hours (Table 3 ).

Preparation and characterization of mucoadhesive NP formulation

In our study, mucoadhesive NP formulation was successfully prepared adapting the spontaneous emulsification technique in accordance with Rençber et al.'s ${ }^{18}$ study. The PS, PI and ZP were found as $217.1 \pm 4.2 \mathrm{~nm}, 0.335 \pm 0.042$, and $26.82 \pm 0.4 \mathrm{mV}$, respectively. To obtain insight into the mechanism of mucoadhesive NP with VRZ: mucin interaction, ZP measurements of their dispersions were performed and the results are shown in Figure $3 \mathrm{~A}$. As seen in Figure $3 \mathrm{~B}$, the absorbance of $0.1 \%$ aqueous mucin
Table 1. Percent recovery and coefficient of variations

\begin{tabular}{|c|c|c|c|}
\hline Concentration & $\begin{array}{l}\text { Injection times } \\
\text { of test solution }\end{array}$ & $\begin{array}{l}\text { Amount found } \\
\text { concentration }(\mu \mathrm{g} / \mathrm{mL})\end{array}$ & Recovery \% \\
\hline \multirow{9}{*}{$10 \mu \mathrm{g} / \mathrm{mL}$} & 1 & 10.111 & 101.113 \\
\hline & 2 & 10.057 & 100.573 \\
\hline & 3 & 10.050 & 100.502 \\
\hline & 4 & 10.076 & 100.761 \\
\hline & 5 & 9.994 & 99.938 \\
\hline & 6 & 9.963 & 99.632 \\
\hline & Mean & 10.042 & 100.420 \\
\hline & S.D. & 0.054 & 0.544 \\
\hline & R.S.D. \% & 0.542 & 0.542 \\
\hline \multirow{9}{*}{$15 \mu \mathrm{g} / \mathrm{mL}$} & 1 & 13.438 & 89.589 \\
\hline & 2 & 13.472 & 89.816 \\
\hline & 3 & 13.517 & 90.115 \\
\hline & 4 & 13.443 & 89.617 \\
\hline & 5 & 13.430 & 89.532 \\
\hline & 6 & 13.432 & 89.546 \\
\hline & Mean & 13.455 & 89.702 \\
\hline & & 0.034 & 0.227 \\
\hline & R.S.D. \% & 0.253 & 0.253 \\
\hline \multirow{9}{*}{$20 \mu \mathrm{g} / \mathrm{mL}$} & 1 & 21.101 & 105.505 \\
\hline & 2 & 21.069 & 105.344 \\
\hline & 3 & 21.099 & 105.497 \\
\hline & 4 & 21.135 & 105.673 \\
\hline & 5 & 21.116 & 105.579 \\
\hline & 6 & 21.081 & 105.403 \\
\hline & Mean & 21.100 & 105.500 \\
\hline & S.D. & 0.024 & 0.118 \\
\hline & R.S.D. \% & 0.112 & 0.112 \\
\hline
\end{tabular}

S.D.: Standard deviation, R.S.D.: Relative standard deviations

dispersion at $\lambda=650 \mathrm{~nm}$ was used as a reference for the turbidimetric study.

The DL capacity of the mucoadhesive NP formulation was found as $99.052 \pm 0.424 \%$. The in vitro VRZ release from the NPs using a dialysis bag for 24 hours is shown in Figure 4.

The values of $n, \log k$, and $r^{2}$ calculated using the Peppas equation were found as $0.7477,0.1946$, and 0.9962 , respectively.

$$
\log \left(\frac{M_{t}}{M_{\infty}}\right)=\log k+n \cdot \log t
$$

where $M_{t} / M_{\infty}$ is the fractional release, $k$ is the diffusional constant, and $\mathrm{n}$ is the diffusional exponent that characterizes the drug release mechanism. 
Table 2. The results of precision study for $10 \mu \mathrm{g} / \mathrm{mL}$ bulk VRZ solution

\begin{tabular}{lllll}
\hline & Repeatability & \multicolumn{3}{l}{ Reproducibility } \\
\hline $\begin{array}{l}\text { Injection times } \\
\text { of } \\
\text { test solution }\end{array}$ & $\begin{array}{l}\text { Amount found } \\
\text { concentration } \\
(\mu \mathrm{g} / \mathrm{mL})\end{array}$ & $\begin{array}{l}\text { Recovery } \\
\%\end{array}$ & $\begin{array}{l}\text { Amount found } \\
\text { concentration } \\
(\mu \mathrm{g} / \mathrm{mL})\end{array}$ & $\begin{array}{l}\text { Recovery } \\
\%\end{array}$ \\
\hline 1 & 10.111 & 101.113 & 10.057 & 100.573 \\
\hline 2 & 10.057 & 100.573 & 10.050 & 100.502 \\
\hline 3 & 10.050 & 100.502 & 10.053 & 100.526 \\
\hline 4 & 10.076 & 100.761 & 10.057 & 100.573 \\
\hline 5 & 9.994 & 99.938 & 10.055 & 100.549 \\
\hline 6 & 10.081 & 100.808 & 10.053 & 100.526 \\
\hline Mean & 10.062 & 100.616 & 10.054 & 100.541 \\
\hline S.D. & 0.039 & 0.395 & 0.003 & 0.028 \\
\hline R.S.D. & 0.392 & 0.392 & 0.028 & 0.028 \\
\hline S.D.S & & &
\end{tabular}

S.D.: Standard deviation, R.S.D.: Relative standard deviations, VRZ: Voriconazole

Table 3. The results of stability study for $10 \mu \mathrm{g} / \mathrm{mL}$ bulk VRZ solution

\begin{tabular}{lll}
$\begin{array}{l}\text { Injection times of test } \\
\text { solution }\end{array}$ & $\begin{array}{l}\text { Amount found } \\
\text { concentration }(\mu \mathrm{g} / \mathrm{mL})\end{array}$ & Recovery \% \\
\hline 1 & 10.057 & 100.573 \\
\hline 2 & 10.048 & 100.479 \\
\hline 3 & 10.041 & 100.408 \\
\hline 4 & 10.041 & 100.408 \\
\hline
\end{tabular}

S.D.: Standard deviation, R.S.D.: Relative standard deviations, VRZ: Voriconazole

\section{DISCUSSION}

HPLC methods have been widely employed in pharmaceutical analysis due to the ease of performance, specificity, sensitivity, and the analysis of samples of complex nature. In this study, HPLC was proposed to quantify VRZ in mucoadhesive NP formulation. Mobile phase selection was based on peak parameters, run time, ease of preparation, and cost. All samples were maintained at $25^{\circ} \mathrm{C}$ in the autosampler prior to injection. A volume of $50 \mu \mathrm{L}$ of each sample was directly injected into the HPLC system. Acceptable separations (Figure 1), with a retention time of 13.669 min for VRZ was obtained using a C-18 column and a mobile phase composed of acetonitril:water (35:65). The column temperature was maintained at $25^{\circ} \mathrm{C}$. Monitoring of VRZ was realised with UV detection at a wavelength of $255 \mathrm{~nm}$.

To be considered specific, an analytical method should demonstrate that it can separate and quantify the drug from impurities, degradation products, and excipients. To evaluate the specificity of the analytical method, the VRZ test solution, methanol, and mobile phase were injected into the chromatographic system. There was no interference from the methanol and mobile phase at VRZ peaks.

The linearity is its ability to elicit test results that are directly or by a well-defined mathematical transformation, proportional
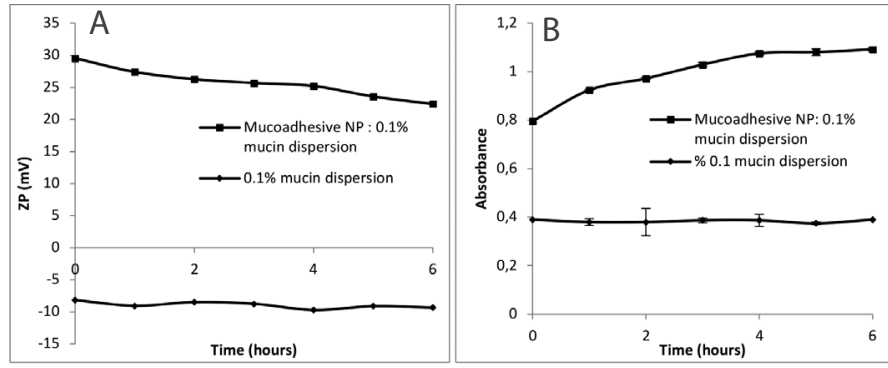

Figure 3. (A) Estimation of the ZP of the mucoadhesive NP during incubation in $0.1 \%$ aqueous mucin dispersion (B) estimation of the interaction between mucoadhesive NP and mucin dispersion by turbidimetric assay

ZP: Zeta potential, NP: Nanoparticle

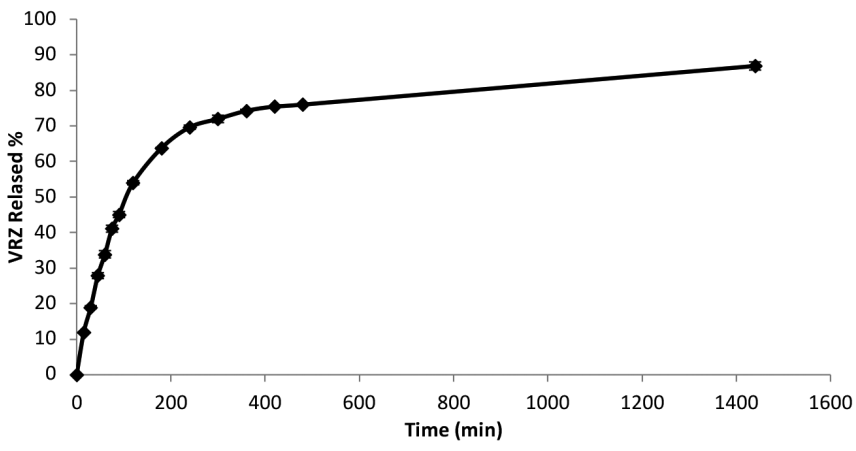

Figure 4. In vitro drug release of mucoadhesive NP VRZ: Voriconazole

to analyte concentration in samples within a given range..$^{23,24}$ Linearity data indicate that the VRZ peak areas are linear over a concentration range of $2.5-30 \mu \mathrm{g} / \mathrm{mL}$. A linear relationship between the peak area and concentration of VRZ was observed. A correlation coefficient was equal to 0.99 , which indicated a strong linear relationship between the variables. The standard deviation of the slope and intercept were low.

The accuracy of an analytical method is the closeness of test results obtained by that method to the true value. It can be defined as the ratio of obtained concentration values to true values and its percentage of recovery. ${ }^{25}$

Precision studies for an analytical procedure are the degree of agreement among individual test results when an analytical method is used repeatedly for multiple samplings of a homogeneous sample under the same conditions. In terms of the method precision study of our experiment, $10 \mu \mathrm{g} / \mathrm{mL}$ solutions were injected six times into the system and the percentage of recovery was evaluated. Because the percentage of recovery has been found almost 100 and the R.S.D. value less than the acceptance criteria, which is $2 \%$, the analysis system for the determination of the assay was verified. The low values of standard deviation denote very good repeatability of the measurement. Thus it was shown that the equipment used for the study were correct and the developed HPLC method was highly repetitive.

The LOD and LOQ tests for the procedure were performed on samples containing very low concentrations of analyses. LOD is 
defined as the lowest amount of analyte in a sample that can be detected above baseline noise, but not necessarily quantitated as an exact value. $L O Q$ is defined as the lowest amount of analyte in a sample that can be reproducibly quantitated above the baseline noise, which gives the signal-to-noise ratio (S/N). ${ }^{26}$

Samples should be tested over at least a 48-hour period and quantitation of components should be determined through comparison with freshly-prepared standards. The stability of VRZ in $10 \mu \mathrm{g} / \mathrm{mL}$ standard solutions was determined by storing the solutions at ambient temperature $\left(25 \pm 1^{\circ} \mathrm{C}\right)$.

The mucoadhesive NP was prepared by adapting the spontaneous emulsification technique previously described by Rençber et al., ${ }^{18}$ which was the avoidance of using toxic organic solvents. This system prolongs the residence time of the dose form at the site of application and facilitates an intimate contact of the dose form with the underlying mucosal surface, and thus contributes to improved and/or better therapeutic performance of the VRZ. The prepared mucoadhesive NP was characterized in terms of PS, PI, ZP, and DL capacity. The mucoadhesive property with two methods of NP was determined. In vitro drug release of $\mathrm{CSH}$-coated NP was performed.

The PS of the NP affects its important properties. The most important properties influenced in pharmaceutical technology are increased saturation solubility and adhesiveness to surfaces/membranes. Pharmaceutically positive effects justify the definition of NPs with a size below $1000 \mathrm{~nm}$, and this size limit should be considered when defining a classification system. ${ }^{27,28}$ Also, PS has a direct relevance to the stability of the formulation. Larger particles tend to aggregate to a greater extent compared with smaller particles, thereby resulting in sedimentation. ${ }^{29}$ The mean size of the prepared mucoadhesive NPs was found as $217.1 \pm 4.2 \mathrm{~nm}$. Previously, Mazzarino et al. ${ }^{30}$ produced CSH-coated NPs for buccal drug delivery and the PS was found around $200 \mathrm{~nm}$. The PI of the formulation was low (PI $<0.5)$, showing that this method of preparation resulted in highly uniform NP. ZP is an important parameter that is key for the potential stability of colloidal systems. Prepared VRZ loaded mucoadhesive formulation was positively charged, with ZP values with $26.82 \pm 0.4 \mathrm{mV}$. Positive ZP may give rise to a strong electrostatic interaction with a negatively charged mucosal surface. ${ }^{31}$ Therefore, we used positively charged NPs for mucoadhesive drug delivery systems as its positively charged surface can be in favour of adhesion to the cell mucosa, which are normally negatively charged.

Two in vitro methods were used to demonstrate the interaction between mucoadhesive NP and mucin. Electrostatic interaction is the most expectable mucoadhesive mechanism. After 6 hours of incubation with mucin, there was a decrease in ZP for mucoadhesive NP, which can probably be attributed to interactions between negatively charged sialic groups in the mucin layer and positively charged surface layer of mucoadhesive NP.27,30 Therefore, it can be concluded that the mucoadhesive NP was able to interact with mucin due to ionic interaction. The turbidity of mucoadhesive NP-mucin aqueous dispersion was examined to obtain information about mucoadhesiveness. The absorbance of the mucin-free dispersion of the NPs did not significantly deviate from 0.4 . Changes in the turbidity of mucoadhesive NP with VRZ:mucin dispersion should be considered as an indication for an eventual interaction between NP and mucin, and not due to the motion of particles. The turbidity of mucoadhesive NP-mucin dispersion was higher than that of mucin dispersion itself (Figure 3). This phenomenon could be explained due to the greater thickness of the CSH layer around these particles, as discussed earlier. Yoncheva et al. ${ }^{32}$ reported that $\mathrm{CSH}$-coated poly(lactide-coglycolide) NP-mucin dispersion demonstrated greater turbidity than mucin itself.

Mucoadhesive NPs with VRZ had high DL capacity ( $99 \%)$. In vitro drug release of mucoadhesive NPs in PBS was studied. The drug release from NPs and subsequent biodegradation are important for developing successful formulations. The release rate of NPs depends upon the desorption of the surface-bound/ adsorbed drug, diffusion through the NP matrix, diffusion through the polymer wall, NP matrix erosion, and a combined erosion/diffusion process. Thus, diffusion and biodegradation govern the process of drug release. ${ }^{33}$ Figure 4 shows that prepared mucoadhesive NP formulation significantly extended the release. No burst effect was observed, indicating that VRZ was homogeneously dispersed in the NP dispersion and that no significant amount of drug was adsorbed onto the NP surface.

The theory of the determination of drug release mechanism from NPs is based on an empirical equation (Ritger \& Peppas, 1987). ${ }^{22}$ The exponent $n$ has been proposed as indicative of the release mechanism. In this study, the value of $n=0.7477$ indicates anomalous (non-Fickian) diffusion. Non-Fickian behavior requires two parameters to describe the coupling of diffusion and relaxation phenomena.

\section{CONCLUSION}

This study has described the mucoadhesive NP formulation of VRZ using a coating polymer of CSH. The method of prepared NPs was consistent and reproducible, and able to obtain colloidal solutions with adequate PS, PI, ZP, acceptable VRZ loading capacity, and appropriate in vitro drug release. The developed HPLC method for VRZ is very simple and specific because all peaks and results confirmed suitable accuracy, specificity, and precision. Therefore, the method could be useful for both routine analytical and quality control assays of VRZ in pharmaceutical formulations. This study has shown that the described mucoadhesive NP formulation containing VRZ is a promising candidate for the local treatment of mucosal diseases. The developed formulation containing VRZ has been found worthy of in vivo studies.

\section{ACKNOWLEDGEMENTS}

The authors gratefully acknowledge Research Foundation of Ege University (12/ECZ/034) for their financial support.

Conflict of Interest: No conflict of interest was declared by the authors. 


\section{REFERENCES}

1. Theurillat R, Zimmerli S, Thormann W. Determination of voriconazole in human serum and plasma by micellar electrokinetic chromatograph. J Pharm Biomed Anal. 2010;53:1313-1318.

2. Herbrecht R, Denning DW, Patterson TF, Bennett JE, Greene RE, Oestmann JW, Kern WV, Marr KA, Ribaud P, Lortholary O, Sylvester R, Rubin RH, Wingard JR, Stark P, Durand C, Caillot D, Thiel E, Chandrasekar PH, Hodges MR, Schlamm HT, Troke PF, de Pauw B; Invasive Fungal Infections Group of the European Organisation for Research and Treatment of Cancer and the Global Aspergillus Study Group. Voriconazole versus amphotericin B for primary therapy of invasive aspergillosis. N Engl J Med. 2002;347:408-415.

3. Perfect JR, Marr KA, Walsh TJ, Greenberg RN, DuPont B, de la Torre-Cisneros J, Just-Nübling G, Schlamm HT, Lutsar I, Espinel-Ingroff A, Johnson E. Voriconazole treatment for less-common, emerging, or refractory fungal infections. Clin Infect Dis. 2003;36:1122-1131.

4. Kullberg BJ, Sobel JD, Ruhnke M, Pappas PG, Viscoli C, Rex JH, Cleary JD, Rubinstein E, Church LW, Brown JM, Schlamm HT, Oborska IT, Hilton $F$, Hodges MR. Voriconazole versus a regimen of amphotericin B followed by fluconazole for candidaemia in non-neutropenic patients: a randomised non-inferiority trial. Lancet. 2005;366:1435-1442.

5. Adams AlH, Bergold AM. Development and Validation of a High Performance Liquid Chromatographic Method for the Determination of Voriconazole Content in Tablets. Chromatographia. 2005;62:429-434.

6. Scott LJ, Simpson D. Voriconazole: a review of its use in the management of invasive fungal infections. Drugs. 2007;67:269-298.

7. Theuretzbacher U, Ihle F, Derendorf H. Pharmacokinetic/pharmacodynamic profile of voriconazole. Clin Pharmacokinet. 2006;45:649-663.

8. Baloglu E, Karavana SY, Ay Senyigit Z, Guneri T. Rheological and Mechanical Properties of Poloxamer Mixtures as a Mucoadhesive Gel Base. Pharm Dev Technol. 2011;16:627-636.

9. Liu M, Zhang J, Zhu X, Shan W, Li L, Zhong J, Zhang Z, Huang Y. Efficient mucus permeation and tight junction opening by dissociable mucus-inert agent coated trimethyl chitosan nanoparticles for oral insulin delivery. J Control Release. 2016;222:67-77.

10. Mazzarino L, Borsali R, Lemos-Senna E. Mucoadhesive films containing chitosan-coated nanoparticles: a new strategy for buccal curcumin release. J Pharm Sci. 2014;103:3764-3771.

11. Almalik A, Donno R, Cadman CJ, Cellesi F, Day PJ, Tirelli N. Hyaluronic acid-coated chitosan nanoparticles: molecular weight-dependent effects on morphology and hyaluronic acid presentation. J Control Release. 2013;172:1142-1150.

12. Cui F, Qian F, Yin C. Preparation and characterization of mucoadhesive polymer-coated nanoparticles. Int J Pharm. 2006;316:154-161.

13. Gundogdu E, Ilem-Ozdemir D, Ekinci M, Ozgenc E, Asikoglu M. Radiolabeling efficiency and cell incorporation of chitosan nanoparticles. J Drug Deliv Sci Technol. 2015;29:84-89.

14. Food and Drug Administration (FDA) (2001). Available at: http://www.fda. gov/cder/guidance/4252fnl.pdf

15. International Conference on Harmonisation (ICH) (2005). Available at: http:// www.ich.org/LOB/media/MEDIA417.pdf

16. Shah VP, Midha KK, Findlay JW, Hill HM, Hulse JD, McGilveray IJ, McKay G, Miller KJ, Patnaik RN, Powell ML, Tonelli A, Viswanathan CT, Yacobi A.
Bioanalytical method validation--a revisit with a decade of progress. Pharm Res. 2000;17:1551-1557.

17. Bodmeier $R$, Chen $H$, Tyle $P$, Jarosz P. Spontaneous formation of drugcontaining acrylic nanoparticles. J Microencapsulation. 1991;8:161-170.

18. Rençber S, Karavana SY, Yılmaz FF, Eraç B, Nenni M, Özbal S, Pekçetin Ç, Gurer-Orhan H, Hoşgör Limoncu M, Güneri P, Ertan G. Development, Characterization and in vivo Assessment of Mucoadhesive Nanoparticles Containing Fluconazole for the Local Treatment of Oral Candidiasis. Int J Nanomedicine. 2016;11:2641-2653.

19. De Campos AM, Diebold Y, Carvalho EL, Sanchez A, Alonso MJ. Chitosan nanoparticles as new ocular drug delivery dystems: in vitro stability, in vivo fate and cellular toxicity. Pharm Res. 2004:21:803-807.

20. Bhatta RS, Chandasana H, Chhonker YS, Rathi C, Kumar D, Mitra K, Shukla PK. Mucoadhesive nanoparticles for prolonged ocular delivery of natamycin: In vitro and pharmacokinetics studies. Int J Pharm. 2012;432:105-112.

21. Yoncheva K, Vandervoort J, Ludwig A. Development of mucoadhesive poly(lactide-co-glycolide) nanoparticles for ocular application. Pharm Dev Technol. 2011;16:29-35.

22. Ritger PL, Peppas NA. A simple equation for description of solute release II. Fickian and anomalous release from swellable devices. J Control Release. 1987;5:37-42.

23. U.S. Pharmacopeia. Available at: http://www.pharmacopeia.cn/v29240/ usp29nf24s0_c1225.html

24. Hacıoğlu A, Çıtlak A, Karakuş S. Development and validation of an HPLC method for determination of nateglinide in drug substances. Marmara Pharm J. 2015;19:103-108.

25. Guideline for Submitting Samples and Analytical Data for Methods Validation. FDA; February 1987.

26. Shabır GA. A Practical Approach to Validation of HPLC Methods Under Current Good Manufacturing Practices. J Validation Tech. 2004:29-37.

27. Abdel-Wahhab MA, Abdel-Wahhab KG, Mannaa FA, Hassan NS, Safar R, Diab R, Foliguet B, Ferrari L, Rinn BH. Uptake of Eudragit Retard L (Eudragit $B$ RL) nanoparticles by human THP-1 cell line and its effects on hematology and erythrocyte damage in rats. Materials (Basel). 2014;7:1555-1572.

28. Keck CM, Müller RH. Nanotoxicological classification system (NCS) - a guide for the risk-benefit assessment of nanoparticulate drug delivery systems. Eur J Pharm Biopharm. 2013;84:445-448.

29. Jain S, Srinath MS, Narendra C, Reddy SN, Sindhu A. Development of a floating dosage form of ranitidine hydrochloride by statistical optimization technique. J Young Pharm. 2010;2:342-329.

30. Mazzarino L, Borsali R, Lemos-Senna E. Mucoadhesive Films Containing Chitosan-Coated Nanoparticles: A New Strategy for Buccal Curcumin Release. J Pharm Sci. 2014;103:3764-3771.

31. Honary S, Zahir F. Effect of Zeta Potential on the Properties of Nano-Drug Delivery Systems-A Review (Part 2). Trop J Pharm Res. 2013;12:265-273.

32. Yoncheva K, Vandervoort J, Ludwig A. Development of mucoadhesive poly(lactide-co-glycolide) nanoparticles for ocular application. Pharm Dev Technol. 2011;16:29-35.

33. Mehta AK, Yadav KS, Sawant KK. Nimodipine Loaded PLGA Nanoparticles: Formulation optimization using factorial design, characterization and in vitro evaluation. Curr Drug Deliv. 2007;4:185-193. 